\title{
EFFECT OF VARYING INTAKE OF PROTEIN AND SALTS ON THE COMPOSITION AND SPECIFIC GRAVITY OF URINE ${ }^{1}$
}

\author{
By MAX MILLER, J. WAIDE PRICE, AND L. P. LONGLEY \\ (From the Department of Medicine, Western Reserve University, \\ and Lakeside Hospital, Cleveland)
}

(Received for publication August 2, 1940)

It has been shown in a previous paper (1) that the specific gravity of urine is a simple additive function of the concentrations of the individual solutes. By the use of appropriate factors, the specific gravity "pattern," i.e., the fraction of the specific gravity accounted for by each of the constituents of the urine, may be calculated when the composition is known. In urine from subjects on a standard 40 or 50 gram protein diet, urea accounted for 15 to 20 per cent, chloride for 25 to 30 per cent, sulfate and phosphate together for 15 to 25 per cent, bicarbonate for 1 to 5 per cent, and creatinine for 1 to 2 per cent of the observed specific gravity. On a 100 or 110 gram protein diet, urea, sulfate, and phosphate made a slightly greater contribution to the specific gravity. On the lower protein diet, 70 to 80 per cent, and on the higher protein diet, 80 to 90 per cent of the specific gravity could be accounted for by the substances determined (urea, creatinine, inorganic salts, and ammonia). The undetermined fraction of specific gravity made up 10 to 30 per cent of the observed value and, in the same urines, the excretion of undetermined solids amounted to 9 to 15 grams daily, which was 10 to 30 per cent of the total solids. The undetermined solids were organic substances, about one-half being organic acids, and the daily excretion increased only slightly when the protein intake was more than doubled. The specific gravity pattern observed in this previous study was remarkably constant, presumably attributable to the fact that the subjects were on relatively uniform diets, particularly with regard to protein and salt intake.

The present study is an extension of this investigation to include the effect of free choice of diet, the influence of specific dietary factors, and the ability of the kidney to vary the composition and specific gravity pattern of urine under ex-

\footnotetext{
1 Supported by a grant from the Commonwealth Fund.
}

perimentally produced changes in the internal environment.

All urine specimens were collected and analyzed as described in the previous paper (1). In cases where the collection period was less than 24 hours, or where the subject was held to a controlled regime, the details are given in the discussion. Sodium and potassium were determined in all cases and the specific gravity contributions of the inorganic constituents were calculated by Method B, previously described.

For analysis of serum the following methods were used: urea, Van Slyke hypobromite; total protein, micro Kjeldahl ; chloride, Van Slyke and Sendroy; phosphate, Fiske and Subbarow (2); creatinine, Rehberg ( 3 ) ; and sulfate, Power and Wakefield (4). Cell volume was determined on the whole blood.

The excretion of water has no effect on the specific gravity pattern of urine when other conditions are kept constant. This was shown in the previous paper where subjects on a controlled diet excreted urines of specific gravity ranging from 1.003 to 1.028 with practically identical patterns.

Since the kidney is not the chief route for excretion of the end products of carbohydrate metabolism, the effect of varying the intake of carbohydrate has not been studied. In all diets, however, sufficient carbohydrate was included to maintain normal fat metabolism and insure adequate caloric intake.

Similarly, the products of normal fat metabolism are not excreted to any great extent in the urine. This was tested in one experiment, as shown in Table I, where fat intake was reduced one-half, protein, carbohydrate, and salt intake remaining constant. On the second day of the low fat intake, a 24-hour specimen was collected. No significant change in the composition or specific gravity pattern was found. Protein intake, on the other hand, is one of the principal factors con- 
TABLE I

Effect of protein and fat on the specific gravity pattern of urire

\begin{tabular}{|c|c|c|c|c|c|c|c|c|c|c|c|c|c|c|c|c|c|}
\hline \multirow{2}{*}{ Date } & \multicolumn{3}{|c|}{ Diet } & \multirow{2}{*}{\begin{tabular}{|} 
Urine \\
volume
\end{tabular}} & \multirow{2}{*}{$\begin{array}{l}\text { Specific } \\
\text { gravity }\end{array}$} & \multirow{2}{*}{$\mathbf{p H}$} & \multirow{2}{*}{$\begin{array}{l}\text { Nitro- } \\
\text { gen } \\
\text { out- } \\
\text { put }\end{array}$} & \multirow{2}{*}{$\begin{array}{c}\text { Blood } \\
\text { urea } \\
\text { nitro- } \\
\text { gen }\end{array}$} & \multirow{2}{*}{$\begin{array}{c}\text { Out- } \\
\text { put } \\
\text { unde- } \\
\text { ter- } \\
\text { mined } \\
\text { solids }\end{array}$} & \multicolumn{8}{|c|}{ Per cent of specific gravity accounted for by } \\
\hline & $\begin{array}{l}\text { Pro- } \\
\text { tein }\end{array}$ & Fat & $\begin{array}{l}\text { Car- } \\
\text { bohy- } \\
\text { drate }\end{array}$ & & & & & & & Urea & $\begin{array}{l}\text { Cre- } \\
\text { ati- } \\
\text { nine }\end{array}$ & $\begin{array}{l}\text { Chlo- } \\
\text { ride }\end{array}$ & SO، & $\left|\mathrm{H}_{2} \mathrm{PO}_{4}\right|$ & $\mathrm{HPO}_{4}$ & $\mathrm{HCO}_{3}$ & Total \\
\hline $\begin{array}{lr}\text { October } & 30,1939 \\
\text { November } 22,1939 \\
\text { February } & 7,1940 \\
\text { Aprll } & 24,1940 \\
\text { April } & 26,1940\end{array}$ & \begin{tabular}{|r|} 
grams \\
\\
19 \\
57 \\
95 \\
150 \\
150
\end{tabular} & \begin{tabular}{|r|} 
erams \\
\\
114 \\
114 \\
89 \\
110 \\
60
\end{tabular} & $\begin{array}{r}\text { grams } \\
350 \\
400 \\
250 \\
170 \\
170\end{array}$ & $\begin{array}{l}c c . \\
1682 \\
1685 \\
1818 \\
1788 \\
1728\end{array}$ & $\begin{array}{l}20^{\circ} / 4^{\circ} \\
1.0080 \\
1.0126 \\
1.0156 \\
1.0167 \\
1.0167\end{array}$ & $\begin{array}{l}7.00 \\
7.30 \\
6.59 \\
5.70 \\
5.52\end{array}$ & $\begin{array}{r}\text { grams } \\
\\
4.5 \\
7.9 \\
14.1 \\
21.9 \\
22.7\end{array}$ & $\begin{array}{c}\text { mem. } \\
\text { per } \\
100 \mathrm{cc} . \\
4.0 \\
10.7 \\
12.7 \\
17.4 \\
17.4\end{array}$ & $\begin{array}{r}\text { srams } \\
\\
9.9 \\
11.6 \\
12.5 \\
17.2 \\
16.9\end{array}$ & $\begin{array}{l}11.7 \\
14.5 \\
21.4 \\
33.4 \\
35.1\end{array}$ & $\begin{array}{l}2.0 \\
1.5 \\
1.2 \\
1.2 \\
1.3\end{array}$ & $\begin{array}{l}41.6 \\
33.8 \\
34.4 \\
17.3 \\
18.0\end{array}$ & $\begin{array}{r}6.9 \\
7.3 \\
11.7 \\
17.4 \\
17.5\end{array}$ & $\begin{array}{r}3.1 \\
1.9 \\
5.5 \\
10.1 \\
11.8\end{array}$ & $\begin{array}{l}6.8 \\
8.8 \\
4.7 \\
1.0 \\
0.8\end{array}$ & $\begin{array}{r}7.2 \\
10.4 \\
2.0\end{array}$ & $\begin{array}{l}79.3 \\
78.2 \\
80.9 \\
80.4 \\
84.5\end{array}$ \\
\hline
\end{tabular}

trolling urine composition and specific gravity pattern, as has been shown in previously presented data. Table I gives data from Subject L. whose protein intake was varied over a greater range, from 19 to 150 grams daily. ${ }^{2}$ In these experiments, the subject remained on each diet until nitrogen excretion indicated equilibrium, and a 24 hour urine specimen was then collected for analysis. Fluid intake was kept constant during all of the urine collection periods.

When salt intake is kept relatively constant, there is a striking correlation between urea or total nitrogen output and the fraction of specific gravity of the urine accounted for by urea. On a 19 gram protein intake, urea accounted for 11.7 per cent, while on a 150 gram intake, this rose to 33.4 per cent. The contribution of sulfate to the specific gravity also increased and the ratio of the contributions of sulfate to urea is constant, varying only between 0.50 to 0.60 . Since the sulphur to nitrogen ratio of urine is essentially constant, this result is to be expected. The phosphate contribution to specific gravity increases only slightly, the increase in phosphorus output being balanced by the shift from $\mathrm{HPO}_{4}=$ to $\mathrm{H}_{2} \mathrm{PO}_{4}^{-}$which occurs with increased protein metabolism and fall in $\mathrm{pH}$. $\mathrm{Bi}$ carbonate plays a significant rôle in the specific gravity pattern on the two lower protein diets be-

2 In this and following tables, data on concentration and output of the urine constituents are not given. Sufficient data are included, however, to make possible the calculation of the concentration or output of urea and creatinine (in millimols or grams) and of the inorganic anions (in milliequivalents) when used in conjunction with the specific gravity factors in Table I of the previous paper (1). A close approximation of the output of salts may be obtained by considering the cation to be sodium alone. cause of the higher $\mathrm{pH}$ values but becomes negligible with greater protein intake. Chloride, since its output is relatively constant, contributes a smaller proportion of the specific gravity as the output of other substances is increased. Creatinine behaves in a similar manner.

The excretion of undetermined solids also varies with protein metabolism, approximately doubling with a five-fold increase in nitrogen output. The increase in the output of undetermined solids with increase in protein metabolism was previously noted but not considered to be definitely significant when 40 or 50 gram and 100 or 110 gram protein diets were compared. The greater protein range covered in these experiments, however, indicates a direct relationship. If the outputs of total solids (grams) and organic acids (milliequivalents) are correlated, a constant value is obtained so that organic acids seem to account for a constant fraction of the undetermined solids, regardless of the diet. The remainder is due to other compounds, the output of which also increases with increased protein metabolism. Change in the fat content of the diet has no effect on the undetermined solids.

The effect of salts on the specific gravity pattern was studied from several aspects: (1) The addition of 10 grams of sodium chloride to the diet, keeping other dietary factors constant, both on 50 gram and 110 gram protein diets (M.); (2) salt depletion produced by removal of salt from the diet coupled with sweating (Z.), by pyloric obstruction (C.), or by minimal salt ingestion with minimal (600 calories) dietary intake (G. M.) ; (3) intravenous injection of concentrated solutions of various salts after a period of water deprivation.

The results of the first two studies are sum- 
TABLE II

Effect of sodium chloride on the specific gravity pattern of urine

\begin{tabular}{|c|c|c|c|c|c|c|c|c|c|c|c|c|c|c|c|}
\hline \multirow{2}{*}{ Sabject } & \multirow{2}{*}{ Date } & \multirow{2}{*}{ Conditions } & \multirow{2}{*}{$\begin{array}{l}\text { Urine } \\
\text { vol- } \\
\text { ume }\end{array}$} & \multirow{2}{*}{$\begin{array}{l}\text { Spe- } \\
\text { cife } \\
\text { gravity }\end{array}$} & \multirow{2}{*}{ pH } & \multicolumn{8}{|c|}{ Per cent of specifio gravity due to: } & \multirow{2}{*}{$\begin{array}{l}\text { Output } \\
\text { Cl as } \\
\mathrm{NaCl}\end{array}$} & \multirow{2}{*}{$\begin{array}{l}\text { Output } \\
\text { unde- } \\
\text { ter- } \\
\text { mined } \\
\text { solids }\end{array}$} \\
\hline & & & & & & Urea & $\begin{array}{l}\text { Creat- } \\
\text { inine }\end{array}$ & $\begin{array}{l}\text { Chlo- } \\
\text { ride }\end{array}$ & $\mathrm{SO}_{4}$ & $\mathrm{H}_{2} \mathrm{PO}_{4}$ & $\mathrm{HPO}_{4}$ & $\mathrm{HCO}_{3}$ & Total & & \\
\hline $\mathbf{M}$ & $\begin{array}{l}\text { October } \quad 4,1939 \\
\text { October } 12,1939\end{array}$ & $\begin{array}{c}50 \text { grams protein-control } \\
50 \text { grams protein-10 grams salt } \\
\text { added }\end{array}$ & $\begin{array}{l}c c . \\
580 \\
995\end{array}$ & $\begin{array}{l}20^{\circ} / 4^{\circ} \\
1.0265 \\
1.0242\end{array}$ & $\begin{array}{l}6.4 \\
6.6\end{array}$ & $\begin{array}{l}20.3 \\
18.5\end{array}$ & $\begin{array}{l}2.3 \\
1.6\end{array}$ & $\begin{array}{l}27.7 \\
38.6\end{array}$ & $\begin{array}{r}10.2 \\
6.5\end{array}$ & $\begin{array}{l}8.3 \\
5.9\end{array}$ & $\begin{array}{l}4.6 \\
5.4\end{array}$ & $\begin{array}{l}0.9 \\
0.9\end{array}$ & $\begin{array}{l}74.3 \\
77.4\end{array}$ & $\begin{array}{c}\text { grams } \\
6.4 \\
14.0\end{array}$ & grams \\
\hline M. & $\begin{array}{l}\text { October } 30,1939 \\
\text { October } \\
31,1939\end{array}$ & $\begin{array}{c}110 \text { grams protein-control } \\
110 \text { grams protein-10 grams salt } \\
\text { added }\end{array}$ & $\begin{array}{l}1010 \\
1220\end{array}$ & $\begin{array}{l}1.0261 \\
1.0264\end{array}$ & $\begin{array}{l}5.9 \\
5.7\end{array}$ & $\begin{array}{l}31.3 \\
24.8\end{array}$ & $\begin{array}{l}1.8 \\
1.5\end{array}$ & $\begin{array}{l}24.7 \\
37.4\end{array}$ & $\begin{array}{l}14.2 \\
10.8\end{array}$ & $\begin{array}{r}11.0 \\
9.8\end{array}$ & $\begin{array}{l}1.8 \\
1.0\end{array}$ & & $\begin{array}{l}84.8 \\
85.3\end{array}$ & $\begin{array}{r}9.8 \\
18.1\end{array}$ & \\
\hline z. & $\begin{array}{lr}\text { February } 27.1940 \\
\text { March } & 4,1940 \\
\text { May } & 1,1940\end{array}$ & $\begin{array}{l}\text { 12-hour specimen-control } \\
\text { 12-hour specimen-control } \\
\text { 12-hour specimen-oalt depletion }\end{array}$ & $\begin{array}{l}226 \\
206 \\
166\end{array}$ & $\begin{array}{l}1.0261 \\
1.0282 \\
1.0296\end{array}$ & $\begin{array}{l}6.01 \\
6.30 \\
5.44\end{array}$ & $\begin{array}{l}18.3 \\
15.2 \\
25.0\end{array}$ & $\begin{array}{l}3.1 \\
2.9 \\
3.7\end{array}$ & $\begin{array}{r}27.1 \\
25.2 \\
0.2\end{array}$ & $\begin{array}{l}10.3 \\
10.6 \\
17.4\end{array}$ & $\begin{array}{l}12.5 \\
12.1 \\
23.6\end{array}$ & $\begin{array}{l}2.5 \\
5.1 \\
1.4\end{array}$ & 0.6 & $\begin{array}{l}73.8 \\
71.7 \\
71.3\end{array}$ & $\begin{array}{l}2.4 \\
2.2 \\
0.02\end{array}$ & $\begin{array}{l}4.5 \\
4.9 \\
4.6\end{array}$ \\
\hline G.M. & 15,1940 & Low protein and salt & 250 & 1.0200 & 6.18 & 25.7 & 3.5 & 3.7 & 6.6 & 7.7 & 2.0 & & 49.2 & 0.44 & 7.4 \\
\hline C. & $\begin{array}{ll}\text { June } & 18,1940 \\
\text { June } & 28,1940\end{array}$ & $\begin{array}{l}\text { Pyloric obstruction } \\
\text { After salt therapy }\end{array}$ & $\begin{array}{r}810 \\
1500\end{array}$ & $\begin{array}{l}1.0227 \\
1.0097\end{array}$ & $\begin{array}{l}6.40 \\
7.00\end{array}$ & $\begin{array}{l}34.1 \\
19.0\end{array}$ & $\begin{array}{l}1.5 \\
1.1\end{array}$ & $\begin{array}{r}0.1 \\
33.0\end{array}$ & $\begin{array}{r}16.1 \\
8.1\end{array}$ & $\begin{array}{r}11.4 \\
5.2\end{array}$ & $\begin{array}{r}5.8 \\
11.8\end{array}$ & $\begin{array}{l}0.4 \\
2.6\end{array}$ & $\begin{array}{l}69.4 \\
80.8\end{array}$ & $\begin{array}{l}0.02 \\
5.4\end{array}$ & $\begin{array}{r}18.5 \\
8.9\end{array}$ \\
\hline
\end{tabular}

marized in Table II. When 10 grams of sodium chloride are added to a diet already containing 6 to 10 grams (M.), the excess is largely excreted within 24 hours with a moderate increase in water excretion (fluid intake was constant for each dietary regime). There is an increase in the chloride fraction of specific gravity from 28 per cent to 39 per cent on the low protein and from 25 per cent to 37 per cent on the high protein diet. The specific gravity contributions of the other constituents are reduced sufficiently so that the total specific gravity accounted for is approximately the same. This reduction is the result of dilution, since the total output of the substance other than chloride was unchanged. This would indicate that the undetermined solids are diluted in the same proportion, although data on this point were not obtained in these experiments with Subject M. The data do show, however, that salt intake, which is quite variable among individuals, plays a very important rôle in fixing the specific gravity pattern.

The effect of salt deprivation on the specific gravity pattern of the urine is shown by Subject $Z$. The urines analyzed in this study are overnight specimens representing the final 12 hours of a 33hour concentration test. On a control diet of 50 grams of protein and a salt intake of approximately 6 grams, the 12 -hour urine specimens show the usual picture found with 24-hour specimens. The subject was then placed on a low salt diet containing 0.5 to 1.0 gram daily and an attempt was made to produce salt depletion by sweating, using the technique described by McCance (5). The average daily loss of chloride in the sweat was 2.5 grams as sodium chloride, thus placing the subject in negative salt balance. The chloride content of the urine fell rapidly, finally reaching a 24-hour output level of less than 0.1 gram, but the serum chloride did not fall lower than 95.6 milliequivalents per liter. The experiment could not be continued beyond this point because of the appearance of alarming symptoms of vasomotor collapse, abdominal and muscular cramps, generalized weakness and mental confusion. At this stage the concentration of urine chloride had fallen to 1.8 milliequivalents per liter, and the specific gravity pattern was definitely altered, all of the other determined substances contributing a substantially increased percentage of the total specific gravity. However, the subject was still able to produce a urine of high specific gravity, 1.0296, although chloride made up only 0.2 per cent of the total. The excretion of undetermined solids was not affected and the percentage of specific gravity accounted for remained at the control level. Since the diminution in salt excretion in these experiments was accompanied by a decrease in water excretion, while the outputs of other substances remained the same, the concentrations of all of these increased sufficiently to raise the specific gravity to a normal level, i.e., the concentrating power of the kidney is unaffected and the hypochloremia in itself does not give rise to hyposthenuria.

Additional evidence for this was obtained from a patient with pyloric obstruction but normal kidney function (Subject C.) whose serum chlorides 
had fallen to 84.0 milliequivalents per liter. In contrast to Subject Z., who showed marked clinical symptoms when serum chloride had fallen only to 96 milliequivalents per liter, there were no symptoms or signs associated with the severe hypochloremia other than a slight degree of dehydration. When fluids were withheld on a 33-hour concentration test, the final 12-hour urine specimen attained a specific gravity of 1.0245 , although practically free of chloride. A 24-hour urine contained only $\mathbf{0 . 0 2}$ gram of chloride as sodium chloride, a concentration of 0.5 milliequivalent per liter, representing a chloride contribution to specific gravity of 0.1 per cent. Urea accounted for 34.1 per cent, more than would be expected from the 24-hour urea nitrogen excretion of 11.7 grams. Sulfate and phosphate contributions were also higher. Here again, the chloride deficit resulted in an increase in the specific gravity contribution of the other constituents.

Undetermined solid output in the 24 hours was 18.5 grams, the highest value thus far encountered. Organic acids were excreted in large amounts also, almost double the average normal output, but the significance of these high values is not apparent.

Another 24-hour urine was collected after the serum chloride level had been restored to normal (104 milliequivalents per liter). In this specimen chloride contributed a normal percentage of the specific gravity and the contributions of the other constituents were modified so that the usual pattern resulted (Table II). The output of organic acids and total solids dropped to normal levels so that the total percentage of specific gravity accounted for was somewhat greater than in the first specimen.

When both protein and salt intake are greatly restricted, the specific gravity pattern shows another change. Subject G. M. was an obese young woman on a reducing diet of extremely low caloric value and salt content. Although this diet placed the subject in a state of moderate ketosis, the urine containing appreciable quantities of acetone bodies, there was no evidence of acidosis either clinically or as shown by blood studies. Kidney function was normal and urine specific gravities above 1.025 were obtained on several occasions. On the day of urine collection the dietary intake consisted of 25 grams of protein, 11 grams of fat, 100 grams of carbohydrate and 0.7 gram of sodium chloride with fluids restricted. Chloride contributed only 3.7 per cent of the specific gravity, sulfate 6.6 per cent, and urea 25.7 per cent. The urea contribution is higher than the protein intake would lead one to expect, again explicable on the basis of low salt excretion with accompanying reduction in water output. In this urine, one-half of the specific gravity is not accounted for, the greatest amount yet encountered. This value is consistent with the fraction of total solids undetermined, also one-half. The output of undetermined solids, in keeping with the low dietary intake, is low, 7.4 grams, despite a high concentration of organic acids, probably ketone bodies.

In this subject, a reduction in the amount of substances to be excreted did not result in hyposthenuria, as suggested by Alving and Van Slyke (6). Water excretion can be correspondingly reduced and a fairly concentrated urine can still be formed. In this case the 24-hour output of total solids was 15.1 grams, as compared to the normal range of 50 to 75 grams, but water output was only $250 \mathrm{cc}$., so that the resulting specific gravity was 1.0200 .

In order to determine the variation in specific gravity pattern due to differences in the choice of diet of normal individuals, 24-hour urines from ten normal adults were studied. These subjects were all in good health, were ambulatory during the collection period, carried on their usual activities, and were allowed unrestricted choice of diet and fluids. The results are arranged in order of nitrogen output in Table III.

In these urines, the nitrogen output ranged from 7.1 to 17.1 grams and chloride output from 90 to 240 milliequivalents (5.3 to 14.0 grams as sodium chloride). The similarity of the specific gravity patterns, despite the variations in diet, is quite striking. It will be noted, also, that the total percentage of specific gravity accounted for, as well as the individual specific gravity contributions of the determined constituents, falls within the range found with the standard 40 to 50 gram and 100 to 110 gram protein diets used in the previous study. The correlation between protein intake and urea specific gravity contribution is not as clear-cut as in the previous experiments due to the greater variation in salt excretion; the latter, as shown above, bearing an inverse relationship to the contributions of the other constituents. 
TABLE III

Specific gravity pattern of urine of ten normal subjects with no dietary restrictions

\begin{tabular}{|c|c|c|c|c|c|c|c|c|c|c|c|c|c|c|c|}
\hline \multirow{2}{*}{ Subject } & \multirow{2}{*}{ Sex } & \multirow{2}{*}{ Date } & \multirow{2}{*}{$\begin{array}{c}\text { Nitro- } \\
\text { gen } \\
\text { output }\end{array}$} & \multirow{2}{*}{$\begin{array}{l}\text { Urine } \\
\text { vol- } \\
\text { ume }\end{array}$} & \multirow{2}{*}{$\begin{array}{l}\text { Specific } \\
\text { gravity }\end{array}$} & \multirow{2}{*}{$\mathbf{p H}$} & \multicolumn{8}{|c|}{ Per cent of specific gravity due to: } & \multirow{2}{*}{$\begin{array}{l}\text { Output } \\
\text { unde- } \\
\text { ter- } \\
\text { mined } \\
\text { solids }\end{array}$} \\
\hline & & & & & & & Urea & $\begin{array}{l}\text { Creat- } \\
\text { inine }\end{array}$ & Chloride & $\mathrm{SO}_{4}$ & $\mathrm{H}_{2} \mathrm{PO}_{4}$ & $\mathrm{HPO}_{4}$ & $\mathrm{HCO}_{2}$ & Total & \\
\hline $\begin{array}{l}\mathbf{J} \\
\mathbf{D} \\
\mathbf{M B} \\
\mathbf{F} \\
\mathbf{H} \\
\mathbf{I B} \\
\mathbf{P} \\
\mathbf{M} \mathbf{P} \\
\mathbf{R} \\
\mathbf{W}\end{array}$ & $\begin{array}{l}\mathbf{F} \\
\mathbf{F} \\
\mathbf{F} \\
\mathbf{M} \\
\mathbf{F} \\
\mathbf{M} \\
\mathbf{F} \\
\mathbf{M} \\
\mathbf{M}\end{array}$ & $\begin{array}{l}\text { October 25, 1939 } \\
\text { November 28, } 1939 \\
\text { November 20,1939 } \\
\text { December } 13,1939 \\
\text { November 2,1939 } \\
\text { November 30, } 1939 \\
\text { October 23, 1939 } \\
\text { December 15, 1939 } \\
\text { December } 18,1939 \\
\text { December } 4,1939\end{array}$ & $\begin{array}{r}\text { grams } \\
7.1 \\
7.8 \\
8.1 \\
8.1 \\
9.6 \\
9.7 \\
10.4 \\
10.7 \\
12.3 \\
17.1\end{array}$ & $\begin{array}{r}c c . \\
1730 \\
550 \\
602 \\
1015 \\
860 \\
2060 \\
1645 \\
1530 \\
2400 \\
1530\end{array}$ & $\begin{array}{c}20^{\circ} / 4^{\circ} \\
1.0079 \\
1.0248 \\
1.0260 \\
1.0146 \\
1.0265 \\
1.0088 \\
1.0110 \\
1.0127 \\
1.0095 \\
1.0191\end{array}$ & $\begin{array}{l}5.79 \\
5.16 \\
5.70 \\
5.26 \\
5.62 \\
6.94 \\
5.57 \\
5.78 \\
6.61 \\
6.08\end{array}$ & $\begin{array}{l}15.7 \\
24.7 \\
23.2 \\
22.0 \\
18.1 \\
20.4 \\
23.8 \\
24.0 \\
21.5 \\
25.4\end{array}$ & $\begin{array}{l}1.7 \\
1.9 \\
1.9 \\
1.8 \\
1.8 \\
1.4 \\
2.4 \\
0.9 \\
1.3 \\
1.5\end{array}$ & $\begin{array}{l}31.9 \\
32.7 \\
32.0 \\
21.1 \\
36.3 \\
35.3 \\
31.0 \\
34.3 \\
24.9 \\
30.0\end{array}$ & $\begin{array}{r}8.0 \\
8.0 \\
5.1 \\
11.4 \\
11.0 \\
7.0 \\
10.4 \\
11.6 \\
10.5 \\
10.4\end{array}$ & $\begin{array}{r}7.7 \\
7.5 \\
15.2 \\
14.2 \\
8.9 \\
3.6 \\
10.3 \\
9.2 \\
8.9 \\
9.9\end{array}$ & $\begin{array}{l}0.9 \\
0.3 \\
1.5 \\
0.6 \\
0.8 \\
6.9 \\
0.7 \\
1.1 \\
8.1 \\
2.4\end{array}$ & $\begin{array}{l}0.3 \\
0.1 \\
0.1 \\
0.1 \\
6.3 \\
0.1 \\
0.1 \\
1.4 \\
0.4\end{array}$ & $\begin{array}{l}66.2 \\
75.0 \\
79.0 \\
71.2 \\
77.0 \\
80.8 \\
78.4 \\
81.2 \\
76.6 \\
80.0\end{array}$ & $\begin{array}{r}\text { grams } \\
15.4 \\
10.6 \\
9.2 \\
12.3 \\
13.3 \\
11.0 \\
11.8 \\
9.8 \\
14.6 \\
16.8\end{array}$ \\
\hline
\end{tabular}

The excretion of undetermined solids in these urines is also within the range found with the standard diets, except for one of 16.8 grams just above the upper limit previously found. There is no correlation between the output of undetermined solids and body weight or surface area.

In order to determine the ability of the kidney to produce marked variations in urine composition and specific gravity pattern under conditions of stress, the following experimental procedure was adopted :

Two subjects with normal kidney function were maintained at rest in bed on a varied diet but restricted to 50 grams of protein and 5 grams of added salt daily. For each experiment, the subject was placed on a standard diet with the same protein and salt content which was not varied for 3 days. Fluid as desired was permitted on the first day but was limited to $600 \mathrm{cc}$. on the second day, and to $200 \mathrm{cc}$. at breakfast on the third day. The 12-hour urine from 7 p.m. of the third day to 7 a.m. of the fourth day was collected (Specimen I). An intravenous injection of a hypertonic solution of urea or a salt was then given over a period of 10 minutes and, beginning 20 minutes later, one (Z.) or two (S.) 3-hour urine specimens (II and III) were collected. The substances used were 25.0 grams of urea, an approximately osmotically equivalent amount of sodium chloride (12.2 grams) or one-half this osmotic equivalent of sodium sulfate $(9.85$ grams) or sodium phosphate (8.45 grams of $\mathrm{Na}_{2} \mathrm{HPO}_{4}$ and 2.05 grams of $\mathrm{NaH}_{2} \mathrm{PO}_{4} \cdot \mathrm{H}_{2} \mathrm{O}, \mathrm{pH}=7.4$ ), in each case dissolved in $50 \mathrm{cc}$. of water. As a control, $50 \mathrm{cc}$. of 5 per cent glucose solution were injected in one experiment with each subject. No food or fluid was allowed until the close of the urine collection periods.

Blood specimens were taken at the close of Period I with both subjects, at the beginning and end of period II with Subject Z., and at the midpoints of Periods II and III with Subject S. Cell volume was determined on whole blood and the sera were analyzed for urea, crea- tinine, total protein, chloride, sulfate, and phosphate. Only the injected substance showed a marked change in concentration in the serum. Slight changes in the other constituents could be attributed to a small increase in water content.

Table IV summarizes the pertinent data from these experiments, giving, in addition to the specific gravity contributions of the determined substances, the urine flow, the specific gravity, the percentage of total solids determined and the blood level of the experimental substance at the end of Period I and at the midpoints of Periods II and III.

Period I, in all experiments, represents urine collected under similar conditions and shows a fairly constant specific gravity pattern consistent with the previously presented data for 24-hour urines. The total percentage of specific gravity determined is also fairly constant, ranging from 72 per cent to 79 per cent with Z., and from 69 per cent to 72 per cent with $S$. The urine output also varies only between narrow limits and is in the lower range of normal rates of excretion, so that a satisfactory concentrating ability is shown in all of these specimens.

Period II shows the changes resulting from the injection of a hypertonic solution when the body is already dehydrated. With both subjects, all four substances cause a significant increase in urine output. Despite the fact that urea and chloride were given in approximately iso-osmolar quantities, while only one-half this osmolar equivalent of sulfate and phosphate was injected, the order of diuretic effect is sulfate $>$ phosphate $>$ urea $>$ chloride. This difference is not evident 
TABLE IV

Effect of intravenous injection of hypertonic solutions on specific gravity pattern of urine

\begin{tabular}{|c|c|c|c|c|c|c|c|c|c|c|c|c|c|c|c|}
\hline \multirow{2}{*}{$\frac{\text { Injected substance. } \ldots \ldots \ldots \ldots \ldots \ldots \ldots \ldots}{\text { Period } \ldots \ldots \ldots \ldots \ldots \ldots \ldots \ldots \ldots \ldots}$} & \multicolumn{3}{|c|}{ Control } & \multicolumn{3}{|c|}{ Orea } & \multicolumn{3}{|c|}{ Chloride } & \multicolumn{3}{|c|}{ Sulfate } & \multicolumn{3}{|c|}{ Phoephate } \\
\hline & I & II & III & I & II & III & I & II & III & I & II & III & I & II & III \\
\hline
\end{tabular}

sUBJact $Z$.

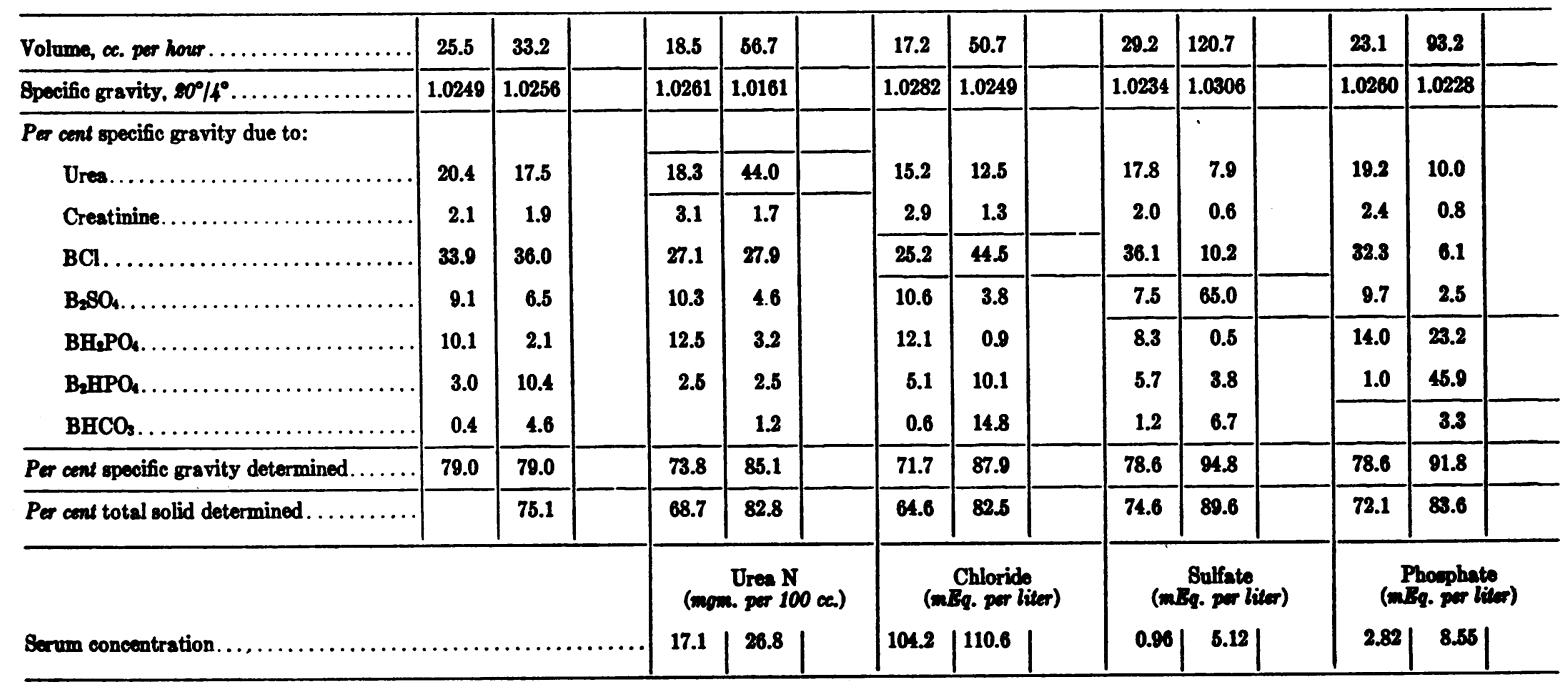

SOBJeT 8 .

\begin{tabular}{|c|c|c|c|c|c|c|c|c|c|c|c|c|c|c|c|}
\hline Volume, ce. per hour. ................... & 26.6 & 18.9 & 33.9 & 11.4 & 64.8 & 71.7 & 19.8 & 54.1 & 45.9 & 14.1 & 98.4 & 39.7 & 16.5 & 96.4 & 50.3 \\
\hline Specific gravity, $800 / 4^{\circ} \ldots \ldots \ldots \ldots \ldots \ldots$ & 1.0231 & 1.0228 & 1.0251 & 1.0258 & 1.0158 & 1.0181 & 1.0256 & 1.0224 & 1.0236 & 1.0262 & 1.0313 & 1.0845 & 1.0271 & 1.0211 & 1.0204 \\
\hline \multicolumn{16}{|l|}{ Per cent specific gravity due to: } \\
\hline Ures.. & 19.0 & 17.9 & 17.4 & 25.3 & 56.0 & 52.8 & 24.3 & 19.3 & 17.3 & 20.2 & 8.5 & 9.1 & 23.7 & 8.9 & 8.0 \\
\hline Crestinine. . & 1.9 & 2.1 & 1.9 & 2.7 & 1.5 & 1.4 & 2.1 & 1.4 & 1.4 & 1.9 & 0.7 & 1.1 & 2.2 & 0.7 & 1.2 \\
\hline BCl. & & 44.1 & 40.5 & 19.2 & 14.7 & 19.6 & 26.5 & 49.5 & 52.1 & 27.0 & 5.0 & 6.8 & 18.4 & 4.1 & 8.8 \\
\hline $\mathbf{B}_{2} \mathrm{SO}_{4} \ldots \ldots \ldots$ & 10.6 & 9.0 & 8.8 & 12.7 & 5.2 & 5.0 & 11.7 & 6.2 & 5.9 & 13.9 & 76.8 & 64.6 & 13.5 & 3.0 & 4.6 \\
\hline $\mathrm{BH}_{2} \mathrm{PO}_{4}$. . & \multirow{3}{*}{$\begin{array}{l}8.7 \\
1.1\end{array}$} & \multirow{3}{*}{$\begin{array}{l}8.2 \\
0.2\end{array}$} & 12.5 & 13.3 & 3.6 & 4.0 & \multirow{3}{*}{$\begin{array}{r}12.2 \\
0.7\end{array}$} & 3.3 & 5.5 & \multirow{3}{*}{$\begin{array}{r}12.9 \\
1.3\end{array}$} & \multirow{3}{*}{$\begin{array}{l}3.2 \\
0.2\end{array}$} & \multirow{3}{*}{$\begin{array}{l}6.0 \\
0.6\end{array}$} & \multirow{3}{*}{$\begin{array}{r}17.4 \\
1.3\end{array}$} & \multirow{3}{*}{$\begin{array}{l}58.8 \\
15.7\end{array}$} & 35.1 \\
\hline $\mathrm{B}_{2} \mathrm{HPO}_{4} \ldots$ & & & 0.4 & 0.9 & 1.0 & 2.8 & & 4.0 & 3.0 & & & & & & 29.8 \\
\hline $\mathrm{BHCO}_{3} \ldots \ldots \ldots \ldots \ldots \ldots$ & & & & & 0.2 & 0.8 & & 1.6 & 1.3 & & & & & & 0.2 \\
\hline Per cent specific gravity determined........ & 77.2 & 81.5 & 81.5 & 74.1 & 82.2 & 86.4 & 77.5 & 85.3 & 86.5 & 77.3 & 94.4 & 88.2 & 76.6 & 91.2 & 85.3 \\
\hline Per cont total solid determined ....... & 72.4 & 75.1 & 78.8 & 69.1 & 82.4 & 82.8 & 72.2 & 82.3 & 80.1 & 69.5 & 86.2 & 79.6 & 70.4 & 86.0 & 78.2 \\
\hline & & & & (mon & $\begin{array}{l}\text { Ureat } N \\
\text { a per } 10\end{array}$ & 0 ce.) & & $\begin{array}{l}\text { Chloride } \\
\text { Bq. per li }\end{array}$ & & & $\begin{array}{l}\text { 8ulfate } \\
\text { lq. per lit }\end{array}$ & & & $\begin{array}{l}\text { hoephate } \\
\text { lq. per bit }\end{array}$ & \\
\hline Serum ooncentration... & & & & 14.4 & 37.4 & 32.2 & 101.5 & 108.1 & 106.3 & 0.78 & 3.86 & 2.20 & 2.64 & 6.56 & $\mathbf{8 . 3 1}$ \\
\hline
\end{tabular}

from the specific gravities which show the most marked lowering with urea and even an increase with sulfate. In the two subjects, the diuresis produced by urea results in a specific gravity decrease of 0.0100 , that by phosphate of 0.0032 and 0.0060 , that by chloride of 0.0033 and 0.0032 , while the diuresis due to sulfate is accompanied by specific gravity increases of 0.0072 and 0.0051 . Thus the effect of salt or urea diuresis on specific gravity depends on the nature of the solute as well as on the increased volume.

With the increase in blood level of the injected substance, it would be expected that the urine would show an increase in concentration of this substance with a decrease in concentration of the other constituents because of the diuresis. This is found to be the case, as is shown by the changes in specific gravity pattern. The one exception is 
bicarbonate whose concentration in the second urine is uniformly increased due to an increase in $\mathrm{pH}$. This morning "alkaline tide" effect has been shown to vary appreciably among individuals and to be independent of food intake (7). It is more evident in Subject Z. than in Subject S. The net result of all of these changes is a great distortion of the specific gravity pattern and a concomitant increase in the percentage of specific gravity determined. In the case of sulfate and phosphate, 91 per cent to 95 per cent of the observed specific gravity has been accounted for.

Period III, representing the second 3-hour period after the injection, shows qualitatively the same picture as Period II but some quantitative differences. In the two periods the specific gravity pattern remains about the same in the urea and chloride experiments while, with sulfate and phosphate, the pattern begins to show a return to the control level. The reason for this is made clear from the excretion data (not given in the table). In round figures, one-fourth of the injected urea is excreted in the first 3-hour period and an equal amount in the second. Similarly, one-sixth of the chloride introduced is eliminated in each of the periods. On the other hand, about 80 per cent of the sulfate is excreted in 3 hours and practically all of the rest in the next 3 hours, while the figures for phosphate are 55 per cent and 25 per cent. The decreased output of the two latter substances in the second 3-hour period is reflected in the decrease in the percentage of specific gravity determined.

Sufficient data are not available to justify a lengthy discussion of the output of undetermined solids in the short periods involved in these experiments. The overnight excretion (Period I) was quite constant, 4.3 to 4.9 grams with Subject Z. and 4.1 to 4.8 grams with Subject S. During Period II, the excretion ranged from 1.4 to 1.9 grams, equivalent to a somewhat greater output when compared to Period I on the same time basis. During Period III, the output (S.) was 1.2 to 1.6 grams. Under normal conditions, the output of undetermined solids is always greater during the day than during the night, which has been interpreted as due to a greater concentration of exogenous metabolites of digestion in the day specimen. Since these subjects, however, had no food until the end of the urine collections, it is possible that diuresis due to salts or urea is responsible for a sweeping out of undetermined substances over a short time interval, which would not be apparent in a collection extending over a longer period. Also, since the calculation of undetermined solids is subject to considerable error, involving as it does all of the errors of the urine analysis, small variations over a short period may be exaggerated or masked. The nature of the undetermined solid is apparently not affected. The specific gravity factor per gram of undetermined solid per liter ranges from 0.00026 to 0.00043 , with an average of 0.00035 (as compared with an average of 0.00039 previously found), with the variations apparently entirely random and showing no consistent upward or downward trend in passing from Period I to Period III.

TABLE V

Effect of intravenous injection of urea and salts on their contributions to specific gravity

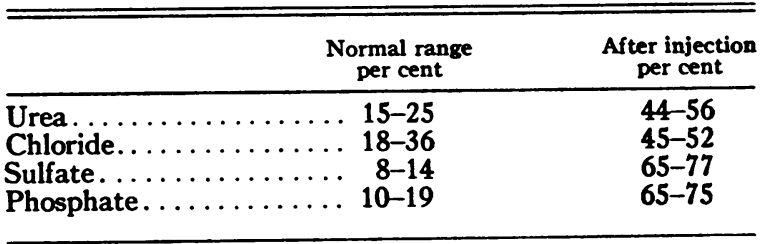

Table $\mathrm{V}$ shows clearly the marked change in the specific gravity contributions which were obtained in these experiments. It is quite possible that these are approaching maximal values under the experimental conditions because, in one subject, the injection of 75 grams of urea in three doses raised the contribution of urea to 58 per cent, only slightly higher than resulted when 25 grams were given, although the blood level reached 64 milligrams of urea nitrogen per $100 \mathrm{cc}$.

It must be emphasized that despite optimal conditions for achieving a high specific gravity in the urine, i.e., low urine flow and high blood concentration, the highest specific gravity obtained in these experiments was 1.0345 . There exists some very effective factor that limits the concentration of the urine. Smith (8) raises the question of two limiting factors to the concentration "ceiling ", an "osmotic ceiling" (urea, sucrose, etc.) and an "ionic strength ceiling" (inorganic salts), the maximal concentration representing a resultant of these two effects. This question, as well as the 
problem of water excretion raised by Gamble (9) requires further investigation.

The ability of the normal kidney, however, to vary the composition and specific gravity pattern of urine below the concentration "ceiling" is clearly shown. Under normal conditions of dietary intake and in health, the kidney eliminates a urine of remarkably uniform composition but it also has a large reserve capacity to take care of changes in the internal environment. How the damaged kidney performs under similar conditions will be dealt with subsequently.

\section{CONCLUSIONS}

1. The normal kidney under the usual conditions of diet produces a urine of remarkably constant composition and specific gravity pattern.

2. Large variations in the intake of water, fat, and carbohydrate have little effect on the specific gravity pattern.

3 . On the other hand, marked changes in protein and salt intake may cause large variations in the composition of urine with a resultant distortion of the specific gravity pattern.

4. When large doses of salts or urea are given intravenously, the injected substance appears in high concentration in the urine and may account for at least 50 per cent to 75 per cent of the specific gravity.

5. The undetermined solids of urine, which account for the undetermined specific gravity, increase with the protein intake but may also be affected by other factors.
6. Chloride depletion per se, produced either experimentally or by pyloric obstruction, does not result in hyposthenuria.

\section{BIBLIOGRAPHY}

1. Price, J. W., Miller, M., and Hayman, J. M., Jr., The relation of specific gravity to composition and total solids in normal human urine. J. Clin. Invest., 1940, 19, 537.

2. Peters, J. P., and Van Slyke, D. D., Quantitative Clinical Chemistry, Vol. II, Methods. Williams and Wilkins Co., Baltimore, 1932.

3. Rehberg, P. B., Ueber die Bestimmung der Menge des glomerulusfiltrats mittels Kreatinin als Nierenfunktionsprüfung, nebst einigen Bemerkungen über die Theorien der Harnbereitung. Zentralbl. f. inn. Med., 1929, 50, 367.

4. Power, M. H., and Wakefield, E. G., A volumetric benzidine method for the determination of inorganic and ethereal sulfate in serum. J. Biol. Chem., 1938, 123, 665.

5. McCance, R. A., Experimental sodium chloride deficiency in man. Proc. Roy. Soc. London, s. B., 1936, 119, 245.

6. Alving, A. S., and Van Slyke, D. D., The significance of concentration and dilution tests in Bright's disease. J. Clin. Invest., 1934, 13, 969.

7. Brunton, C. E., The acid output of the kidney and the so-called alkaline tide. Physiol. Rev., 1933, 13, 372.

8. Smith, H. W., The Physiology of the Kidney. Oxford University Press, New York, 1937.

9. Gamble, J. L., Extracellular fluid; renal defense of extracellular fluid: control of acid-base excretion and the factors of water expenditure. (William Sydney Thayer and Susan Read Thayer lecture.) Bull. Johns Hopkins Hospital, 1937, 61, 174. 